\title{
Aliphatic Substitution of $o$-Carboranyl Phenols Enhances Estrogen Receptor Beta Selectivity
}

\author{
Kiminori Ohta, ${ }^{a}$ Takumi Ogawa,${ }^{a}$ Asako Kaise,${ }^{a}$ Akifumi Oda,${ }^{b}$ and Yasuyuki Endo*,a \\ ${ }^{a}$ Faculty of Pharmaceutical Sciences, Tohoku Pharmaceutical University; 4-4-1 Komatsushima, Aoba-ku, Sendai \\ 981-8558, Japan: and ${ }^{b}$ Faculty of Pharmacy, Institute of Medical, Pharmaceutical and Health Sciences, Kanazawa \\ University; Kakuma-machi, Kanazawa, Ishikawa 920-1192, Japan.
}

Received October 10, 2013; accepted January 20, 2014

The two subtypes of estrogen receptor (ER), ER $\alpha$ and $E R \beta$, differ greatly in expression pattern and biological functions, and ER $\beta$-selective ligands candidates to treat immune-related disorders. ER $\beta$-selective ligands have mostly been designed based the idea of introducing a substituent that interferes sterically with the ligand's interaction with Met421 to selectively decrease the affinity for ER $\alpha$ (the equivalent residue in ER $\beta$ is Ile373). Therefore, we designed and synthesized a series of carboranyl phenol derivatives bearing an aliphatic substituent as candidate ER $\beta$-selective ligands. Introduction of a longer aliphatic substituent into the carboranyl moiety enhanced the ER $\beta$ selectivity of $o$-carboranyl phenol derivatives 4 , but not $m$-carboranyl bisphenol derivatives 5. Compound 4c showed 7.4-fold ER $\beta$ selectivity in ER-binding assay and exhibited moderate estrogenic activity in cell proliferation assay using MCF-7 cell line.

Key words carborane; estrogen receptor; subtype selectivity; estrogenic activity; docking study

We have shown that the carborane cage is available as a novel hydrophobic pharmacophore for drug development, ${ }^{1}$ and since then, various carborane-containing bioactive compounds have been reported. ${ }^{2,3)}$ Prior to that, carboranes had been used only as boron carriers for boron neutron capture therapy (BNCT), based on their high boron content. ${ }^{4)} \mathrm{We}$ also designed and synthesized various carborane-containing bioactive compounds as candidate nuclear receptor ligands. ${ }^{5-8)}$ One derivative, 1-(4-hydroxyphenyl)-12-hydroxymethyl- $p$-carborane (BE120, 1), shows more potent estrogenic activity than the endogenous female hormone estrogen, estradiol (E2, 2, Fig. 1). ${ }^{1,9,10)}$ Subsequently, many carboranyl phenol derivatives have been synthesized and their estrogen-related biological activities examined. ${ }^{11-18)}$ Compounds that either induce or inhibit cellular estrogenic responses are used for estrogen replacement therapy after menopause or the treatment of breast cancer, respectively. ${ }^{19-21)}$ Tissue-selective ligands, which act as agonists for bone metabolism and as antagonists for the female reproductive systems (known as selective estrogen receptor modulators, SERMs) are widely used for the treatment of osteoporosis. ${ }^{22}$

The estrogen receptor subtypes ER $\alpha^{23)}$ and $\mathrm{ER} \beta^{24)}$ are expressed in breast and uterus and in bone, colon, endothelial cells, bladder, and areas of the brain important for cognition, respectively. Most ER modulators are non-selective for ER subtypes, but it has been proposed that compounds with ER subtype selectivity would be useful as third-generation SERMs. ${ }^{25,26)}$ Harris et al. showed that $\mathrm{ER} \beta$-selective ligands
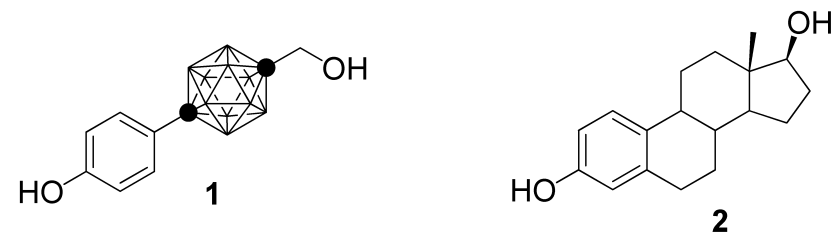

Fig. 1. Structures of Carborane-Containing Estrogen BE120 1 and Estradiol 2

The authors declare no conflict of interest. may be therapeutically useful to treat chronic intestinal and joint inflammation by modulating the immune response. ${ }^{27)}$ Thus, ER $\beta$-selective ligands are of interest as potential clinical candidates and also as probes for ER $\beta$-related molecular biology.

The X-ray crystal structures of receptor-ligand complexes of $\mathrm{ER} \alpha$ and $\mathrm{ER} \beta$ show that their binding pockets are quite similar. ${ }^{28)}$ Binding of $\mathbf{2}$ to the ligand binding domains (LBDs) of the two ERs is illustrated in Fig. 2. The same amino acid residues are involved in hydrogen bonding with the two hydroxyl groups of $\mathrm{E} 2$ in the LBDs of $\mathrm{ER} \alpha$ and $\mathrm{ER} \beta$, and thus E2 is accommodated equally well by the two LBDs. However, in the hydrophobic pocket of the LBDs, Leu384 and Met421 of ER $\alpha$ are substituted by Met336 and Ile373 in ER $\beta$, respectively (Fig. 2). Compound 3 is an $E R \beta$-selective ligand which was designed based the idea of decreasing the affinity for ER $\alpha$ by introducing a $n$-butyl group that interferes sterically with Met 421 of $E R \alpha^{29)}$ (Fig. 3).

We have synthesized a range of carboranyl phenol derivatives and have discovered various types of ER modulators, partial agonists, super-agonists, antagonists, and SERMs. ${ }^{11-18)}$ In addition, our quantitative structure-activity relationship (QSAR) studies of very simple carboranyl phenols showed that the hydrophobicity of the carborane cage is significantly correlated with ER $\alpha$-binding affinity. ${ }^{30,31)}$ Although carbora-

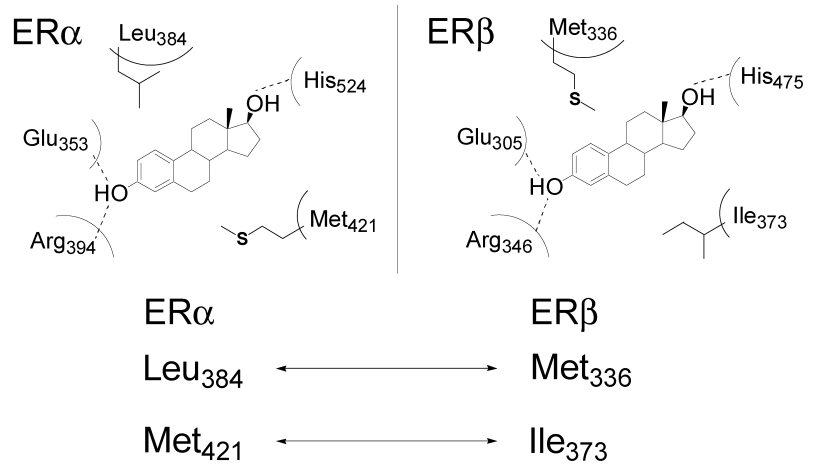

Fig. 2. Differences of Amino Acid Residues around the ER LBDs 
nyl phenol is a privileged structure as an ER ligand, little is known about the effect of aliphatic substituents on the carborane cage. Therefore, we designed and synthesized carboranyl phenol derivatives $\mathbf{4}$ and $\mathbf{5}$ with aliphatic substituents on the carborane cage for examination of their $\operatorname{ER} \beta$ selectivity and estrogenic activities. From the viewpoints of ease of synthesis and the directions of the aliphatic substituents, we focused on $o$-carboranyl phenol and $m$-carboranyl bisphenol as being most relevant to drug design.

Synthesis of $o$-carboranyl phenol derivatives $4 \mathbf{a}-\mathbf{c}$ is summarized in Chart 1. 4-Methoxyphenyl-o-carborane 6, which

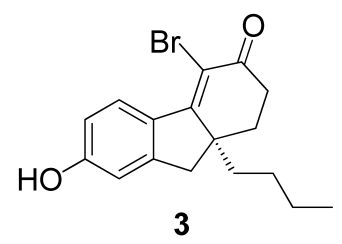

ER $\beta$ selective ligand

Fig. 3. Structure of ER $\beta$ Selective Ligand 3 was synthesized by the literature procedure, was reacted with ethyl iodide or allyl bromide in the presence of $\mathrm{NaH}$ as a base to afford $C$-ethyl or $C$-allyl intermediates in $77 \%$ or $50 \%$ yield, respectively. Demethylation of the methoxy group of 7 with $\mathrm{BBr}_{3}$ afforded the target compounds $\mathbf{4 a}$ and $\mathbf{b}$ in $96 \%$ and $60 \%$ yields, respectively. The allyl group of compound $4 \mathrm{~b}$ was reduced by catalytic hydrogenation using $\mathrm{Pd} / \mathrm{C}$ to afford the corresponding $C$ - $n$-propyl derivative $4 \mathbf{c}$ in $80 \%$ yield.

Chart 2 summarizes the synthesis of $m$-carboranyl bisphenol derivatives 5a and b. 7-Iodo- $m$-carborane 8 was obtained by iodination of $m$-carborane. ${ }^{32)}$ Grignard reagents, which were freshly prepared from $\mathrm{Mg}$ turnings and the corresponding halide, were reacted with $\mathbf{8}$ by Pd-catalyzed coupling reaction to afford $B$-allyl and $B$ - $n$-butyl $m$-carborane in $99 \%$ and $61 \%$ yields, respectively. ${ }^{33)}$ They were treated with $n$-butyl lithium to obtain the lithium salts, which were transformed into copper salts with $\mathrm{Cu}(\mathrm{I}) \mathrm{Cl}$, and converted to the diaryl- $m$-carboranes $\mathbf{1 0 a}$ and $\mathbf{b}$ in $37 \%$ and $39 \%$ yields, respectively. ${ }^{34,35)} B$ - $n$-Propyl derivative 5a was synthesized by catalytic hydrogenation of the allyl group of $\mathbf{1 0 a}$, followed by deprotection of the phenol group with $\mathrm{BBr}_{3}$ in $45 \%$ yield over

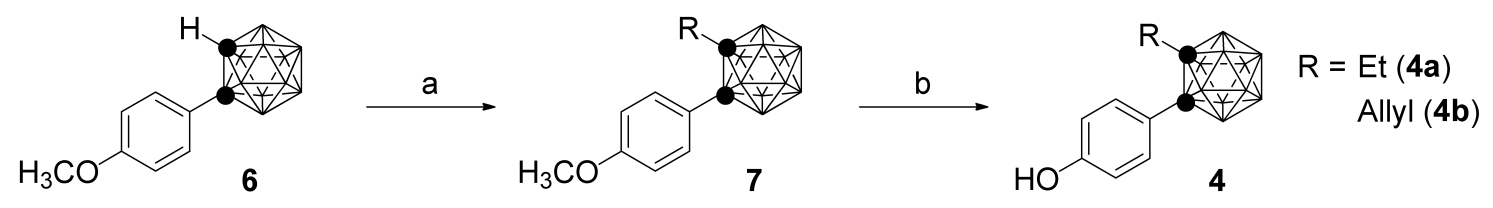

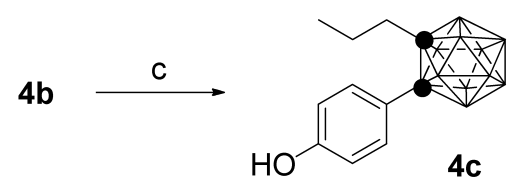

Reagents and conditions: a) $\mathrm{NaH}$, ethyl iodide or allyl bromide, DMF, rt; b) $\mathrm{BBr}_{3}, \mathrm{CH}_{2} \mathrm{Cl}_{2}$, rt; c) $\mathrm{Pd} / \mathrm{C}, \mathrm{H}_{2}, \mathrm{MeOH} / \mathrm{AcOEt}$, rt.

Chart 1. Synthesis of $o$-Carborane Derivatives $\mathbf{4 a - c}$

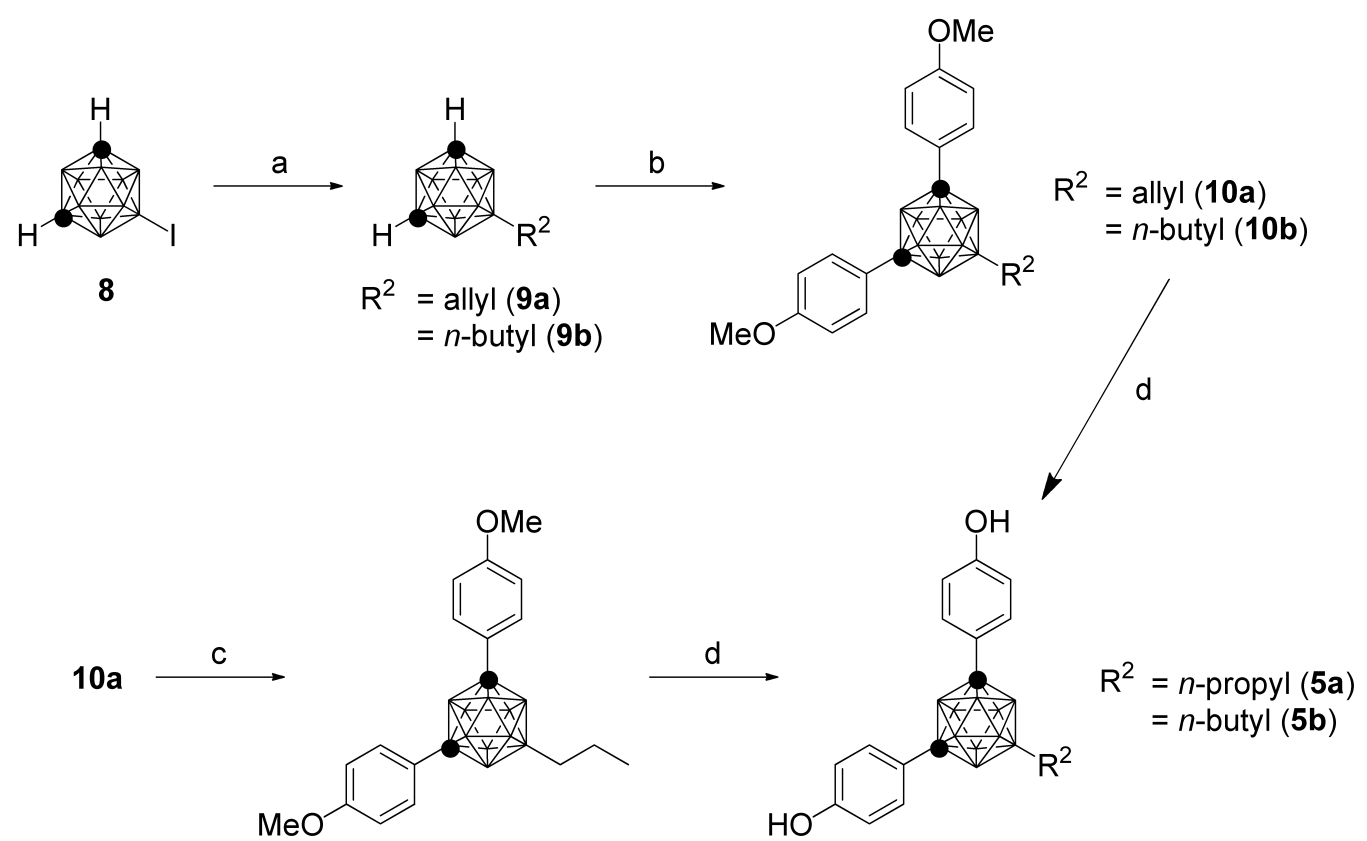

Reagents and conditions: a) Grignard reagents, $\mathrm{Pd}\left(\mathrm{PPh}_{3}\right)_{2} \mathrm{Cl}_{2}, \mathrm{Cu}(\mathrm{I}) \mathrm{I}, \mathrm{THF}$, reflux; b) i) $n$ - $\mathrm{BuLi}$, DME, rt, ii) $\mathrm{Cu}(\mathrm{I}) \mathrm{Cl}, \mathrm{pyridine}, 4$-iodoanisole, $100^{\circ} \mathrm{C}$; c) $\mathrm{Pd} / \mathrm{C}, \mathrm{H}_{2}, \mathrm{MeOH} /$ AcOEt, rt; d) $\mathrm{BBr}_{3}, \mathrm{CH}_{2} \mathrm{Cl}_{2}$, rt.

Chart 2. Synthesis of $m$-Carborane Derivatives 5a and $\mathbf{b}$ 
the 2 steps. Compound $\mathbf{5 b}$ was obtained by deprotection of the phenol group of $\mathbf{1 0 b}$ in $82 \%$ yield.

The ER binding affinities of the synthesized compounds were evaluated by means of competitive ER binding assays using $\left[2,4,6,7-{ }^{3} \mathrm{H}\right] 17 \beta$-estradiol and human recombinant $\mathrm{ER} \alpha$ and ER $\beta .^{36)}$ Table 1 summarized the relative binding affinity (RBA) values, estimated based on the RBA of estradiol 2, taken as 100. All the test compounds $\mathbf{4}$ and $\mathbf{5}$ bound to the ERs in a dose-dependent manner. Introduction of substituents onto the carborane cage decreased the binding affinity for both ERs. As the substituent was lengthened, the $o$-carboranyl phenol derivatives 4 showed a decrease of binding affinity for both ERs, but the decrease was more marked for ER $\alpha$. Compound $4 \mathrm{a}$ showed weak binding affinity for ER $\alpha$ but its binding affinity for $\operatorname{ER} \beta$ was higher than that of E2. This may suggest that ethyl group has an unfavorable steric interaction with the hydrophobic pocket of $\mathrm{ER} \alpha$, but not that of $\mathrm{ER} \beta$. The RBA values of allyl derivative $\mathbf{4 b}$ were decreased for both ERs. The allyl group is more polar than a $n$-propyl group and would be disfavored in a hydrophobic environment. Compound $4 \mathbf{c}$ showed a high RBA value with 7.4-fold selectivity for ER $\beta$. These results show that introduction of an alkyl group onto the carborane cage markedly influences the ER $\beta$ selectivity. On the other hand, $m$-carborane bisphenol derivatives $\mathbf{5 a}$ and b showed little ER-subtype selectivity. We previously found that non-substituted $m$-carborane bisphenol had a similar RBA value to E2, while introduction of an alkylamino group into the second phenol group greatly decreased the binding affinity and changed the functional activity from ER agonist to ER antagonist. ${ }^{37)}$ It seems that the phenol group is accommodated in a secondary hydrophobic pocket and forms hydrogen bonds in both ER LBDs.

A docking simulation of $\mathrm{hER} \alpha$ (PDB: 1ERE) and $\mathrm{hER} \beta$ (PDB: 2I0G) with the carborane containing ligands, 4c and $\mathbf{5 b}$, was performed with an automatic docking program (GOLD 5.2) ${ }^{38)}$ A docking mode of $\mathbf{4 c}$ in the hER $\beta$ LBD is shown in Fig. 4a. The highly hydrophobic $o$-carborane cage and $n$-propyl group are located in the hydrophobic pocket of the receptor, but the $o$-carborane cage of $\mathbf{4 c}$ is close to Ile 373 of $\operatorname{hER} \beta$, contrary to our hypothesis (Fig. 4a). Interestingly, the arrangement of $4 c$ in the LBDs of ER $\alpha$ is different from that in $\operatorname{ER} \beta$ (Fig. $4 \mathrm{~b}$ ) and $n$-propyl group of $4 \mathrm{c}$ is close to Met421 in the hER $\alpha$ LBD (Fig. 4a). We suggested that the $\mathrm{ER} \beta$ selectivity of $\mathbf{4 c}$ is caused by the steric repulsion between the $n$-propyl group and Met421 of hER $\alpha$. A docking study of $\mathbf{5 b}$ with hERs showed that the second phenol group is accommodated in the secondary hydrophobic pocket of both ER LBDs (data not shown). The decrease of binding affinity and the poor selectivity of $\mathbf{5 b}$ for ERs may suggest that the direction of $n$-butyl group is not suitable for steric repulsion to occur with Met421 of ER $\alpha$.

Next, we evaluated the agonist and antagonist activities of the most $\mathrm{ER} \beta$-selective compound $\mathbf{4 c}$ by means of cell proliferation assay using the MCF-7 cell line, which shows estrogen-dependent growth. ${ }^{36)}$ Compound $\mathbf{4 c}$ promoted cell proliferation in a dose-dependent manner and the $\mathrm{EC}_{50}$ value was $3.0 \times 10^{-9} \mathrm{M}$ (Fig. 5). When the maximum potency $\left(E_{\max }\right)$ of E2 was taken as $100 \%$, that of $4 \mathbf{c}$ was $110 \%$. Thus, compound $4 \mathbf{c}$ is simply a weaker ER full agonist.

In conclusion, we examined the effect of introducing an aliphatic substituent into the carborane cage of $o$ - or $m$-carboranyl phenol derivatives based on the structure of a well-known $\mathrm{ER} \beta$-selective ligand 3. Interestingly, the $\operatorname{ER} \beta$ selectivity of $o$-carboranyl phenol derivatives 4 was enhanced as the length of the substituent was increased, whereas $m$-carboranyl phenol derivatives 5 showed little $\operatorname{ER} \beta$ selectivity. The $C$ - $n$-propyl $o$-carboranyl phenol $\mathbf{4 c}$ showed 7.4-fold ER $\beta$ selectivity in ERbinding assay and moderate estrogenic activity in MCF-7 cell proliferation assay. These results provide useful information on substituent effects to guide research aimed at discovery of selective carborane-containing estrogen modulators.

\section{Experimental}

General Considerations Melting points were determined with a Yanaco micro melting point apparatus and were not corrected. ${ }^{1} \mathrm{H}$ - and ${ }^{13} \mathrm{C}$-NMR spectra were recorded with JEOL JNM-EX-270 and JNM-LA-400 spectrometers. Chemical shifts of ${ }^{1} \mathrm{H}-\mathrm{NMR}$ signals were referenced to tetramethylsilane $(0.0 \mathrm{ppm})$ as an internal standard. Chemical shifts of ${ }^{13} \mathrm{C}$-NMR signals were referenced to residual ${ }^{13} \mathrm{C}$ present in deuterated solvents. The splitting patterns are designated as follows: $\mathrm{s}$ (singlet), d (doublet), t (triplet), m (multiplet), q (quartet), and br (broad). Mass spectra were recorded on a JEOL JMSDX-303 spectrometer. Column chromatography was carried out using Fuji Silysia BW80s and TLC was performed on Merck silica gel $\mathrm{F}_{254}$. Carboranes were purchased from Katchem s.r.o. Other chemicals were purchased from Aldrich or Tokyo Kasei Ltd. and used without further purification, or

Table 1. Binding Affinity for ER $\alpha$ and $\mathrm{ER} \beta$ and Subtype Selectivity of Compounds $\mathbf{4}$ and $\mathbf{5}$

\begin{tabular}{|c|c|c|c|c|}
\hline \multirow{2}{*}{ Compound } & \multirow{2}{*}{$\mathrm{R}$} & \multicolumn{2}{|c|}{$\mathrm{RBA}^{a}$} & \multirow{2}{*}{ Selectivity ER $\beta / \mathrm{ER} \alpha$} \\
\hline & & $\mathrm{ER} \alpha$ & $\mathrm{ER} \beta$ & \\
\hline $4 a$ & Ethyl & 43.7 & 140.7 & 3.2 \\
\hline $4 b$ & Allyl & 9.3 & 44.9 & 4.8 \\
\hline $4 c$ & $n$-Propyl & 11.8 & 87.0 & 7.4 \\
\hline $5 a$ & $n$-Propyl & 27.6 & 21.7 & 0.8 \\
\hline $5 \mathbf{b}$ & n-Butyl & 32.4 & 43.5 & 1.3 \\
\hline E2 (1) & & 100 & 100 & 1.0 \\
\hline
\end{tabular}

a) Relative binding affinity with respect to that of estradiol $\mathbf{2}$ taken as $100 \%$. All binding assays were performed in duplicate $(n=2)$ and the numbers are average values. 
(a)

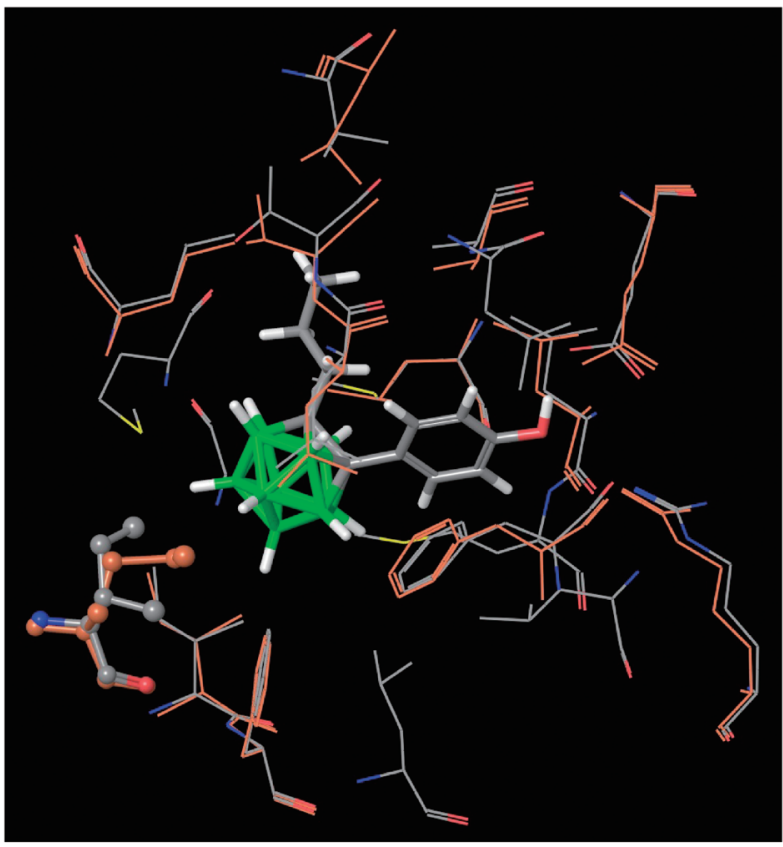

(b)

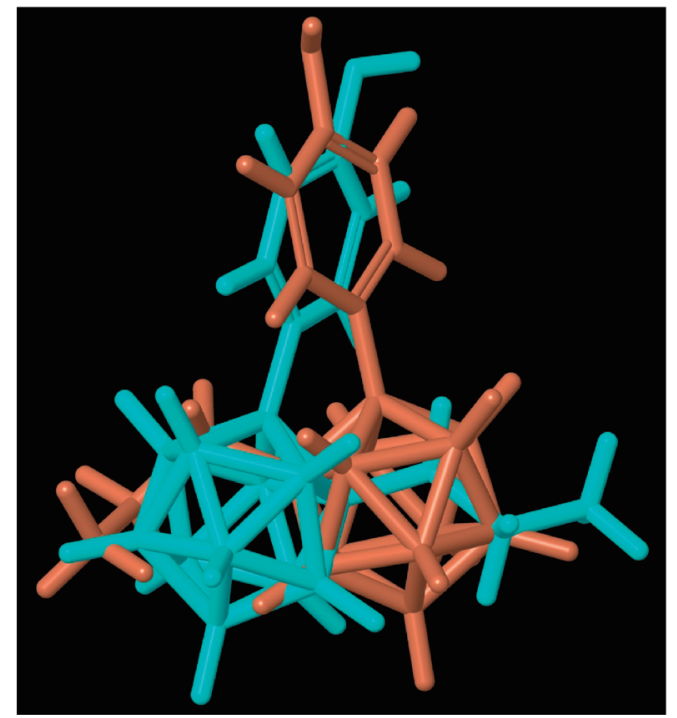

Fig. 4. Docking Model of $\mathbf{4 c}$ to the LBDs of $\operatorname{ER} \alpha$ and $\operatorname{ER} \beta$

(a) Docking mode of $\mathbf{4 c}$ in the hER $\beta$ LBD (atom colors: H (white) B (green), C (gray), N (blue), O (red) and $\mathrm{S}$ (yellow)). The corresponding amino acid residues of hER $\alpha$ are colored orange. Both Ile 373 of ER $\beta$ and Met421 of ER $\alpha$ are displayed with a ball and stick model. (b) The arrangements of $4 \mathbf{c}$ in the LBDs of ER $\alpha$ (brown) and ER $\beta$ (aqua).

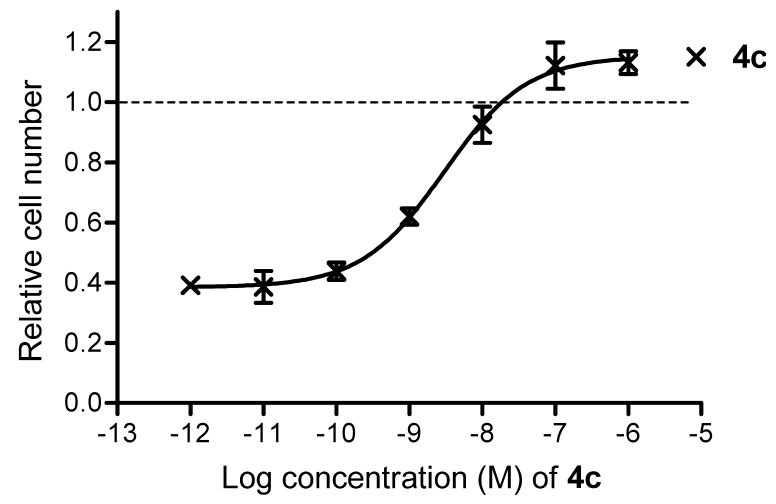

Fig. 5. Dose-Response Curve of Compound $\mathbf{4 c}$ in MCF-7 Cell Proliferation Assay

MCF-7 cells were incubated with $4 \mathbf{c}\left(1 \times 10^{-6}\right.$ to $\left.1 \times 10^{-12} \mathrm{M}\right)$ for $4 \mathrm{~d}$, and the results are shown as relative cell number, with the value for $0.1 \mathrm{~nm}$ estradiol taken as 1 . Dashed line shows $E_{\max }$ of E2. Cell proliferation assays was performed in triplicate $(n=3)$. Values are means \pm S.D. for separate experiments.

were prepared according to procedures described in the literature. All solvents were commercial products of reagent grade, and were used without further purification.

General Procedure of $\boldsymbol{C}$-Alkylation of 6 To a solution of $\mathbf{6}$ in dry $\mathrm{N}, \mathrm{N}$-dimethylformamide (DMF) was added $\mathrm{NaH}$ (1.2 eq) at $0^{\circ} \mathrm{C}$ under an argon (Ar) atmosphere, and the mixture was stirred for $30 \mathrm{~min}$ at the same temperature. Alkyl halide (1.2 eq) was added, and stirring was continued at room temperature for $2.5 \mathrm{~h}$. The reaction mixture was poured onto ice and extracted with $\mathrm{Et}_{2} \mathrm{O}$. The organic layer was washed with brine, dried over $\mathrm{Na}_{2} \mathrm{SO}_{4}$, and concentrated. The residue was purified by silica gel column chromatography with $1: 20$ AcOEt- $n$-hexane to give the corresponding $C$-alkylated compound.

1-(4-Methoxyphenyl)-2-ethyl-1,2-dicarba-closo-dodecaborane: Colorless solid; $77 \%$ yield; ${ }^{1} \mathrm{H}-\mathrm{NMR}\left(400 \mathrm{MHz}, \mathrm{CDCl}_{3}\right)$ $\delta$ (ppm): 0.97 (t, $J=7.7 \mathrm{~Hz}, 3 \mathrm{H}), 1.60-3.60$ (br m, 10H), 1.85 (q, $J=7.7 \mathrm{~Hz}, 2 \mathrm{H}), 3.82$ (s, 3H), 6.87 (d, $J=9.2 \mathrm{~Hz}, 2 \mathrm{H}), 7.53$ (d, $J=9.2,2 \mathrm{H})$; MS (electron ionization (EI)) $m / z 278\left(\mathrm{M}^{+}, 100 \%\right)$.

1-(4-Methoxyphenyl)-2-allyl-1,2-dicarba-closo-dodecaborane: Colorless solid; 50\% yield; ${ }^{1} \mathrm{H}-\mathrm{NMR}\left(400 \mathrm{MHz}, \mathrm{CDCl}_{3}\right)$ $\delta$ (ppm): 1.60-3.60 (brm, 10H), 2.53 (d, $J=7.7 \mathrm{~Hz}, 2 \mathrm{H}), 3.83$ (s, $3 \mathrm{H}), 4.73-4.79(\mathrm{~m}, 1 \mathrm{H}), 5.03(\mathrm{~d}, J=10.1 \mathrm{~Hz}, 1 \mathrm{H}), 5.56-5.68(\mathrm{~m}$, $1 \mathrm{H}), 6.88$ (d, $J=8.7 \mathrm{~Hz}, 2 \mathrm{H}), 7.54$ (d, $J=8.7,2 \mathrm{H})$; MS (EI) $\mathrm{m} / \mathrm{z}$ $290\left(\mathrm{M}^{+}, 100 \%\right)$.

General Procedure of Demethylation of 7 To a solution of 6 in $\mathrm{CH}_{2} \mathrm{Cl}_{2}$ was added a solution of $1 \mathrm{M} \mathrm{BBr}_{3}$ (1.2 eq) in $\mathrm{CH}_{2} \mathrm{Cl}_{2}$ at $-78^{\circ} \mathrm{C}$, and the mixture was stirred at room temperature for $30 \mathrm{~h}$, then poured onto ice and extracted with AcOEt. The organic layer was washed with brine, dried over $\mathrm{Na}_{2} \mathrm{SO}_{4}$, and concentrated. The residue was purified by silica gel column chromatography with $1: 5 \mathrm{AcOEt}-n$-hexane to give the phenol derivative 4 .

1-(4-Hydroxyphenyl)-2-ethyl-1,2-dicarba-closo-dodecaborane (4a): 96\% yield; colorless needles (AcOEt- $n$-hexane); mp 106.5-108.0 ${ }^{\circ} \mathrm{C}$; ${ }^{1} \mathrm{H}-\mathrm{NMR}\left(400 \mathrm{MHz}, \mathrm{CDCl}_{3}\right) \delta$ (ppm): $0.97(\mathrm{t}$, $J=7.7 \mathrm{~Hz}, 3 \mathrm{H}$ ), $1.60-3.60$ (brm, $10 \mathrm{H}), 1.85$ (q, $J=7.7 \mathrm{~Hz}, 2 \mathrm{H}$ ), 5.25 (brs, 1H), $6.81(\mathrm{~d}, J=9.2 \mathrm{~Hz}, 2 \mathrm{H}), 7.50(\mathrm{~d}, J=8.7,2 \mathrm{H})$. MS (EI) m/z $264\left(\mathrm{M}^{+}, 100 \%\right)$; high resolution (HR)-MS Calcd for $\mathrm{C}_{10} \mathrm{H}_{20} \mathrm{~B}_{10} \mathrm{O}$ : 264.2517, Found: 264.2521.

1-(4-Hydroxyphenyl)-2-allyl-1,2-dicarba-closo-dodecaborane (4b): $60 \%$ yield; colorless needles $\left(\mathrm{CH}_{2} \mathrm{Cl}_{2}-n\right.$-hexane); $\mathrm{mp}$ 96.0-97.5 ${ }^{\circ} \mathrm{C}$; ${ }^{1} \mathrm{H}-\mathrm{NMR}\left(400 \mathrm{MHz}, \mathrm{CDCl}_{3}\right) \delta$ (ppm): 1.60-3.60 (brm, 10H), 2.54 (d, J=7.2 Hz, 2H), 4.72-4.79 (m, 1H), 5.03 (d, $J=10.1 \mathrm{~Hz}, 1 \mathrm{H}), 5.34$ (brs, 1H), 5.56-5.68 (m, 1H), 6.81 (d, $J=8.7 \mathrm{~Hz}, 2 \mathrm{H}), 7.50$ (d, $J=8.7,2 \mathrm{H}) ; \mathrm{MS}$ (EI) $\mathrm{m} / \mathrm{z} 276$ $\left(\mathrm{M}^{+}, 100 \%\right)$; HR-MS Calcd for $\mathrm{C}_{11} \mathrm{H}_{20} \mathrm{~B}_{10} \mathrm{O}: 276.2517$, Found: 276.2516 .

1-(4-Hydroxyphenyl)-2-n-propyl-1,2-dicarba-closo-dodecaborane (4c): To a solution of $\mathbf{4 b}(25 \mathrm{mg})$ in AcOEt $(5 \mathrm{~mL})$ and $\mathrm{MeOH}(5 \mathrm{~mL})$ was added Pd on carbon $(5 \mathrm{mg})$ and the mixture 
was stirred at room temperature for 30 min under a hydrogen atmosphere. The mixture was filtered, the residue was washed with AcOEt, and the organic layer was concentrated. The residue was purified by silica gel column chromatography with 1:5 AcOEt- $n$-hexane to give $4 \mathbf{c}(21 \mathrm{mg}, 80 \%)$ as colorless solid. Colorless oil; ${ }^{1} \mathrm{H}-\mathrm{NMR}\left(400 \mathrm{MHz}, \mathrm{CDCl}_{3}\right) \delta$ (ppm): 0.74 (t, $J=7.2 \mathrm{~Hz}, 3 \mathrm{H}), 1.60-3.60$ (brm, 10H), 1.41 (sext, $J=7.7 \mathrm{~Hz}$, $2 \mathrm{H}), 1.73$ (t, $J=8.7 \mathrm{~Hz}, 2 \mathrm{H}), 5.45$ (brs, $1 \mathrm{H}), 6.82(\mathrm{~d}, J=8.7 \mathrm{~Hz}$, 2H), 7.49 (d, J=8.7, 2H); MS (EI) $m / z 278\left(\mathrm{M}^{+}, 100 \%\right)$; HR-MS Calcd for $\mathrm{C}_{11} \mathrm{H}_{22} \mathrm{~B}_{10} \mathrm{O}$ : 278.2674, Found: 278.2678.

General Procedure of Synthesis of 9 A solution of Grignard reagent (4 eq) was added dropwise to a stirred dry tetrahydrofuran (THF) solution $(10 \mathrm{~mL})$ of $\mathbf{8}(1.0 \mathrm{~g}, 3.70 \mathrm{mmol})$ at $0^{\circ} \mathrm{C}$ under an $\mathrm{Ar}$ atmosphere, and stirring was continued at room temperature for $30 \mathrm{~min}$. Bis(triphenylphosphine)palladium(II) dichloride (260 mg, $0.37 \mathrm{mmol}$ ) and cupper(I) iodide $(70.5 \mathrm{mg}, 0.37 \mathrm{mmol})$ were added in one portion, and the reaction mixture was refluxed for $60 \mathrm{~h}$. After removal of the solvent, $\mathrm{Et}_{2} \mathrm{O}$ was added to the residue and the excess Grignard reagent was destroyed by slow addition of $10 \% \mathrm{HCl}$ aqueous solution. The organic phase was separated from the mixture, and the aqueous layer was extracted with $\mathrm{Et}_{2} \mathrm{O}$. The combined organic phase was washed with water and brine, dried over $\mathrm{Na}_{2} \mathrm{SO}_{4}$, and concentrated. The residue was purified by column chromatography on silica gel with $n$-hexane to afford the corresponding 9.

9-Allyl-1,7-dicarba-closo-dodecaborane (9a): 99\% yield; ${ }^{1} \mathrm{H}-\mathrm{NMR}\left(400 \mathrm{MHz}, \mathrm{CDCl}_{3}\right) \delta$ (ppm): 1.40-3.50 (brm, 9H), 1.78 (brs, 2H), 2.88 (brs, 2H), 4.75-4.90 (m, 2H), $5.86(\mathrm{~m}$, 1H); MS (EI) $m / z 184\left(\mathrm{M}^{+}, 100 \%\right)$.

9-n-Butyl-1,7-dicarba-closo-dodecaborane (9b): 61\% yield; ${ }^{1} \mathrm{H}-\mathrm{NMR}\left(400 \mathrm{MHz}, \mathrm{CDCl}_{3}\right) \delta$ (ppm): 0.80-0.95 (m, 5H), 1.30-1.40 (m, 5H), 1.40-3.50 (brm, 9H), 2.85 (brs, 2H); MS (EI) $m / z 200\left(\mathrm{M}^{+}, 100 \%\right)$.

General Procedure of Synthesis of $\mathbf{1 0}$ To a solution of $9(350 \mathrm{mg})$ in 1,2-dimethoxyethane (DME) (3 mL) was added dropwise a solution of $2.66 \mathrm{M} n$-BuLi in hexane (2.2 eq) at $0^{\circ} \mathrm{C}$ under an $\mathrm{Ar}$ atmosphere, and the mixture was stirred for $30 \mathrm{~min} . \mathrm{Cu}(\mathrm{I}) \mathrm{Cl}(2.2 \mathrm{eq})$ was added in one portion, and stirring was continued at room temperature for $1 \mathrm{~h}$. Pyridine (15 eq) and $p$-iodoanisole (2eq) were added in one portion, and the mixture was refluxed for $20 \mathrm{~h}$, then cooled to room temperature, and diluted with AcOEt. Insoluble materials were filtered off through Celite. The filtrate was washed with $10 \% \mathrm{HCl}$ aqueous solution, $10 \% \quad \mathrm{Na}_{2} \mathrm{~S}_{2} \mathrm{O}_{3}$ aqueous solution, water and brine, dried over $\mathrm{Na}_{2} \mathrm{SO}_{4}$, and concentrated. The residue was purified by silica gel column chromatography with $1: 30$ to 1:20 AcOEt- $n$-hexane to give the corresponding $\mathbf{1 0}$.

1,7-Bis-(4-methoxyphenyl)-9-allyl-1,7-dicarba-closo-dodecaborane (10a): 37\% yield; ${ }^{1} \mathrm{H}-\mathrm{NMR}\left(400 \mathrm{MHz}, \mathrm{CDCl}_{3}\right) \delta$ (ppm): 1.60-3.60 (brm, 9H), 1.86 (d, $J=7.2 \mathrm{~Hz}, 2 \mathrm{H}), 3.76$ (s, $6 \mathrm{H}), 4.80-4.93(\mathrm{~m}, 2 \mathrm{H}), 5.91(\mathrm{~m}, 1 \mathrm{H}), 6.75(\mathrm{~d}, J=8.7 \mathrm{~Hz}, 4 \mathrm{H})$, 7.36 (d, $J=9.2 \mathrm{~Hz}, 4 \mathrm{H})$; MS (EI) $m / z 396\left(\mathrm{M}^{+}, 100 \%\right)$.

1,7-Bis-(4-methoxyphenyl)-9-n-butyl-1,7-dicarba-closo-dodecaborane (10b): 39\% yield; ${ }^{1} \mathrm{H}-\mathrm{NMR}\left(400 \mathrm{MHz}, \mathrm{CDCl}_{3}\right) \delta$ (ppm): $0.87-0.96(\mathrm{~m}, 5 \mathrm{H}), 1.31-1.41(\mathrm{~m}, 4 \mathrm{H}), 1.60-3.60$ (brm, 9H), 3.78 (s, 6H), $6.76(\mathrm{~d}, J=8.7 \mathrm{~Hz}, 4 \mathrm{H}), 7.37$ (d, $J=8.7 \mathrm{~Hz}$, $4 \mathrm{H})$; MS (EI) $m / z 412\left(\mathrm{M}^{+}, 100 \%\right)$.

1,7-Bis-(4-methoxyphenyl)-9-n-propyl-1,7-dicarba-closododecaborane The title compound was prepared by the same method as described for the synthesis of $\mathbf{4 c}$. 55\% yield;
${ }^{1} \mathrm{H}-\mathrm{NMR}\left(400 \mathrm{MHz}, \mathrm{CDCl}_{3}\right) \delta$ (ppm): 0.92 (t, $\left.J=8.3 \mathrm{~Hz}, 2 \mathrm{H}\right)$, 0.97 (t, $J=7.3 \mathrm{~Hz}, 3 \mathrm{H}$ ), 1.43 (sext, $J=7.8 \mathrm{~Hz}, 2 \mathrm{H}$ ), 1.60-3.60 (brm, 9H), 3.77 (s, 6H), $6.76(\mathrm{~d}, J=8.8 \mathrm{~Hz}, 4 \mathrm{H}), 7.37$ (d, $J=8.8 \mathrm{~Hz}, 4 \mathrm{H})$.

1,7-Bis-(4-hydroxyphenyl)-9-n-propyl-1,7-dicarba-closo-dodecaborane (5a): 82\% yield; colorless oil; ${ }^{1} \mathrm{H}-\mathrm{NMR}(400 \mathrm{MHz}$, $\left.\mathrm{CDCl}_{3}\right) \delta(\mathrm{ppm}): 0.91(\mathrm{t}, J=7.7 \mathrm{~Hz}, 2 \mathrm{H}), 0.96(\mathrm{t}, J=7.2 \mathrm{~Hz}, 3 \mathrm{H})$, 1.42 (sext, $J=7.2 \mathrm{~Hz}, 2 \mathrm{H}$ ), 1.60-3.60 (brm, 9H), 5.32 (brs, 2H), $6.69(\mathrm{~d}, J=8.7 \mathrm{~Hz}, 4 \mathrm{H}), 7.31(\mathrm{~d}, J=8.7 \mathrm{~Hz}, 4 \mathrm{H})$; MS (EI) $m / z 370\left(\mathrm{M}^{+}, 100 \%\right)$; HR-MS Calcd for $\mathrm{C}_{17} \mathrm{H}_{26} \mathrm{~B}_{10} \mathrm{O}_{2}: 370.2936$, Found: 370.2943 .

1,7-Bis-(4-hydroxyphenyl)-9-n-butyl-1,7-dicarba-closo-dodecaborane (5b): Quant; colorless oil; ${ }^{1} \mathrm{H}-\mathrm{NMR}(400 \mathrm{MHz}$, $\left.\mathrm{CDCl}_{3}\right) \quad \delta$ (ppm): $0.86-0.96(\mathrm{~m}, 5 \mathrm{H}), 1.30-1.43(\mathrm{~m}, 4 \mathrm{H})$, 1.60-3.60 (brm, 9H), 5.82 (brs, 2H), 6.69 (d, $J=8.7 \mathrm{~Hz}, 4 \mathrm{H})$, 7.31 (d, $J=8.7 \mathrm{~Hz}, 4 \mathrm{H})$; MS (EI) $m / z 384\left(\mathrm{M}^{+}, 100 \%\right)$; HR-MS Calcd for $\mathrm{C}_{18} \mathrm{H}_{28} \mathrm{~B}_{10} \mathrm{O}_{2}$ : 384.3092, Found: 384.3094 .

Competitive Binding Assay for ERs Ligand binding to estrogen receptors $\alpha(\mathrm{ER} \alpha)$ and $\beta(\mathrm{ER} \beta)$ was determined by the nitrocellulose filter binding assay method. ER $(0.5 \mu \mathrm{g} /$ tube, PanVera Co., Ltd.) was diluted with binding assay buffer (20 mm Tris- $\mathrm{HCl} \mathrm{pH} 8.0,0.3 \mathrm{M} \mathrm{NaCl}, 1 \mathrm{~mm}$ ethylenediaminetetraacetic acid (EDTA) $\mathrm{pH}$ 8.0, $10 \mathrm{~mm}$ 2-mercaptoethanol, $0.2 \mathrm{~mm}$ phenylmethylsulfonyl fluoride) and incubated with $4 \mathrm{~nm}\left[6,7-{ }^{3} \mathrm{H}\right] 17 \beta$-estradiol in the presence or absence of an unlabeled competitor at $4^{\circ} \mathrm{C}$ for $18 \mathrm{~h}$. The incubation mixture was absorbed by suction onto a nitrocellulose membrane that had been soaked in binding assay buffer. The membrane was washed twice with buffer $(20 \mathrm{~mm}$ Tris- $\mathrm{HCl} \mathrm{pH} 8.0,0.15 \mathrm{M}$ $\mathrm{NaCl}$ ) and then with $25 \%$ ethanol in distilled water. Radioactivity that remained on the membrane was measured in Atomlight (NEN) by using a liquid scintillation counter.

Cell Culture At $80 \%$ confluence, cells of the human breast adenocarcinoma cell line MCF-7 were trypsinized from the maintenance dish with $0.25 \%$ trypsin-EDTA and collected by centrifugation $\left(4^{\circ} \mathrm{C}, 1500 \mathrm{rpm}, 5 \mathrm{~min}\right)$. The supernatant was removed, $1 \mathrm{~mL}$ of Dulbecco's modified Eagle's medium (DMEM) supplemented with 10\% fetal bovine serum (FBS), $100 \mathrm{IU} / \mathrm{mL}$ penicillin and $100 \mathrm{mg} / \mathrm{mL}$ streptomycin was added, and cell aggregates were broken up by thorough pipetting. Cells were seeded in a dish at a concentration of $4 \times 10^{4}$ cell/ $\mathrm{mL}$ or $8 \times 10^{4}$ cell $/ \mathrm{mL}$, and cultivated at $37^{\circ} \mathrm{C}$ in a $5 \% \mathrm{CO}_{2}$ humidified incubator. Cells were routinely cultivated $2 \mathrm{~d}$ or $3 \mathrm{~d}$ later.

Cell Proliferation Assay Cells of the human breast adenocarcinoma line MCF-7 were routinely cultivated in DMEM supplemented with $10 \%$ FBS, $100 \mathrm{IU} / \mathrm{mL}$ penicillin and $100 \mathrm{mg} / \mathrm{mL}$ streptomycin at $37^{\circ} \mathrm{C}$ in an incubator under an atmosphere of $5 \% \mathrm{CO}_{2}$ in air. On the day before assay, MCF-7 cells were switched to DMEM (low glucose phenol red-free supplemented with 5\% sFBS, $100 \mathrm{IU} / \mathrm{mL}$ penicillin and $100 \mathrm{mg} / \mathrm{mL}$ streptomycin). Cells were trypsinized from the maintenance dish into phenol red-free trypsin-EDTA and seeded in a 96-well plate at a density of $2 \times 10^{3}$ cells per final volume of $100 \mu \mathrm{L}$ DMEM supplemented with $5 \%$ sFBS, $100 \mathrm{IU} / \mathrm{mL}$ penicillin and $100 \mathrm{mg} / \mathrm{mL}$ streptomycin. After $24 \mathrm{~h}$, the medium was replaced with $90 \mu \mathrm{L}$ of fresh DMEM and $10 \mu \mathrm{L}$ of drug solution, supplemented with serial dilutions of 4-OH-Tam or DMSO as the dilution control in the presence or absence of $1 \times 10^{-11} \mathrm{M}$ E2, was added to triplicate microcultures. Cells were incubated for $4 \mathrm{~d}$, and medium with $4-\mathrm{OH}-$ 
Tam in the presence or absence of $1 \times 10^{-11} \mathrm{M}$ E2 was replaced once after $3 \mathrm{~d}$. At the end of the incubation time, proliferation was evaluated by using a cell counting kit. WST-8 $(10 \mu \mathrm{M})$ was added to microcultures and cells were incubated for $2 \mathrm{~h}$. The absorbance at $450 \mathrm{~nm}$ was measured. This parameter is related to the number of living cells in the culture.

Docking Study Three-dimensional (3D) structures of protein-ligand complexes were predicted by GOLD 5.2 software with default settings. ${ }^{38)}$ The 3D structure of human ER $\alpha$ and $\beta$ used in this study was retrieved from the Protein DataBank (PDB) (PDB ID: 1ERE and 2I0G, respectively). Missing hydrogen atoms in the crystal structure were computationally added by Hermes. ${ }^{39)}$ The center of the active site was defined as the center of the ligand in 1ERE and $2 \mathrm{I} 0 \mathrm{G}$ for $\mathrm{ER} \alpha$ and $\beta$, respectively, and the active site radius was set to $10.0 \AA$. The structural optimizations of ligands were carried out by B3LYP/6-31G(d,p) using Gaussian 09, Revision C.01. ${ }^{40)}$ The cavities of ER were detected by Q-SiteFinder. ${ }^{41)}$ PDB entries 1ERE and 2I0G were used as 3D structures of $\mathrm{ER} \alpha$ and $\beta$ similar to the docking study. Ten sites were output for each protein and the sites were ranked by volume (default setting).

Acknowledgments This research was supported by a Grant-in-Aid from the Strategic Research Program for Private Universities (2010-2014), a Grant-in-Aid for Scientific Research (B) (No. 20390035) and a Grant-in-Aid for Young Scientists (B) (No. 21790116) from the Ministry of Education, Culture, Sports, Science and Technology of Japan.

\section{References}

1) Iijima T., Endo Y., Tsuji M., Kawachi E., Kagechika H., Shudo K., Chem. Pharm. Bull., 47, 398-404 (1999).

2) Ban H. S., Minegishi H., Shimizu K., Maruyama M., Yasui Y., Nakamura H., ChemMedChem, 5, 1236-1241 (2010).

3) Page M. F. Z., Jalisatgi S. S., Maderna A., Hawthorne M. F., Synthesis, 2008, 555-563 (2008).

4) Soloway A. H., Tjarks W., Barnum B. A., Rong F.-G., Barth R. F., Codogni I. M., Wilson J. G., Chem. Rev., 98, 1515-1562 (1998).

5) Goto T., Ohta K., Fujii S., Ohta S., Endo Y., J. Med. Chem., 53, 4917-4926 (2010).

6) Fujii S., Goto T., Ohta K., Hashimoto Y., Suzuki T., Ohta S., Endo Y., J. Med. Chem., 48, 4654-4662 (2005).

7) Endo Y., Iijima T., Kagechika H., Ohta K., Kawachi E., Shudo K., Chem. Pharm. Bull., 47, 585-587 (1999).

8) Endo Y., Yoshimi T., Kimura K., Itai A., Bioorg. Med. Chem. Lett., 9, 2561-2564 (1999).

9) Endo Y., Iijima T., Yamakoshi Y., Yamaguchi M., Fukasawa H., Shudo K., J. Med. Chem., 42, 1501-1504 (1999).

10) Endo Y., Iijima T., Yamakoshi Y., Fukasawa H., Miyaura C., Inada M., Kubo A., Itai A., Chem. Biol., 8, 341-355 (2001).

11) Endo Y., Iijima T., Yamakoshi Y., Kubo A., Itai A., Bioorg. Med. Chem. Lett., 9, 3313-3318 (1999).

12) Endo Y., Yoshimi T., Iijima T., Yamakoshi Y., Bioorg. Med. Chem. Lett., 9, 3387-3392 (1999).

13) Endo Y., Yoshimi T., Yamakoshi Y., Chem. Pharm. Bull., 48, 312 314 (2000)

14) Endo Y., Yoshimi T., Miyaura C., Pure Appl. Chem., 75, 1197-1205 (2003).

15) Endo Y., Yoshimi T., Ohta K., Suzuki T., Ohta S., J. Med. Chem., 48, 3941-3944 (2005).

16) Ogawa T., Ohta K., Iijima T., Suzuki T., Ohta S., Endo Y., Bioorg. Med. Chem., 17, 1109-1117 (2009).

17) Ohta K., Ogawa T., Suzuki T., Ohta S., Endo Y., Bioorg. Med.
Chem., 17, 7958-7963 (2009).

18) Ohta K., Ogawa T., Endo Y., Bioorg. Med. Chem. Lett., 22, 4728 4730 (2012).

19) Constantine G. D., Pickar J. H., Curr. Opin. Pharmacol., 3, 626634 (2003).

20) Leng X.-H., Bray P. F., Drug Discovery Today: Disease Mechanisms, 2, 85-91 (2005).

21) Motivala A., Pitt B., Drugs, 67, 647-655 (2007).

22) Labrie F., Labrie C., Belanger A., Simard J., "Selective Estrogen Receptor Modulators," ed. by Manni A., Verderame M., Humana Press Inc., Totowa, NJ, 2002.

23) Green S., Walter P., Kumar V., Krust A., Bornert J. M., Argos P., Chambon P., Nature (London), 320, 134-139 (1986).

24) Kuiper G. G. J. M., Enmark E., Pelto-Huikko M., Nilsson S., Gustafsson J., Proc. Natl. Acad. Sci. U.S.A., 93, 5925-5930 (1996).

25) Minutolo F., Macchia M., Katzenellenbogen B. S., Katzenellenbogen J. A., Med. Res. Rev., 31, 364-442 (2011).

26) Kuiper G. G., Carlsson B., Grandien K., Enmark E., Häggblad J., Nilsson S., Gustafsson J. A., Endocrinology, 138, 863-870 (1997).

27) Harris H. A., Albert L. M., Leathurby Y., Malamas M. S., Mewshaw R. E., Miller C. P., Kharode Y. P., Marzolf K. J., Komm B. S., Winneker R. C., Frail D. E., Henderson R. A., Zhu Y., Keith J. C. Jr., Endocrinology, 144, 4241-4249 (2003).

28) Brzozowski A. M., Pike A. C., Dauter Z., Hubbard R. E., Bonn T., Engstrom O., Ohman L., Greene G. L., Gustafsson J. A., Carlquist M., Nature (London), 389, 753-758 (1997).

29) Wilkening R. R., Ratcliffe R. W., Tynebor E. C., Wildonger K. J., Fried A. K., Hammond M. L., Mosley R. T., Fitzgerald P. M. D., Sharma N., McKeever B. M., Nilsson S., Carlquist M., Thorsell A., Locco L., Katz R., Frisch K., Birzin E. T., Wilkinson H. A., Mitra S., Cai S., Hayes E. C., Schaeffer J. M., Rohrer S. P., Bioorg. Med. Chem. Lett., 16, 3489-3494 (2006).

30) Yamamoto K., Endo Y., Bioorg. Med. Chem. Lett., 11, 2389-2392 (2001).

31) Endo Y., Yamamoto K., Kagechika H., Bioorg. Med. Chem. Lett., 13, 4089-4092 (2003).

32) Zakharkin L. I., Ol'shevskaya V. A., Poroshina T. Yu., Balagurova E. V., Zh. Obshch. Khim., 57, 2012-2016 (1987).

33) Kovredov A. I., Shaugumbekova Zh. S., Petrovskii P. V., Zakharkin L. I., Zh. Obshch. Khim., 59, 607-611 (1989).

34) Coult R., Fox M. A., Gill W. R., Herbertson P. L., MacBride J. A. H., Wade K., J. Organomet. Chem., 462, 19-29 (1993).

35) Ohta K., Goto T., Endo Y., Inorg. Chem., 44, 8569-8573 (2005).

36) Ohta K., Chiba Y., Ogawa T., Endo Y., Bioorg. Med. Chem. Lett., 18, 5050-5053 (2008).

37) Ogawa T., Ohta K., Yoshimi T., Yamazaki H., Suzuki T., Ohta S., Endo Y., Bioorg. Med. Chem. Lett., 16, 3943-3946 (2006).

38) Jones G., Willett P., Glen R. C., J. Mol. Biol., 245, 43-53 (1995).

39) Hermes 5.2, CCDC Software Ltd., Cambridge, U.K., 2013.

40) Frisch M. J., Trucks G. W., Schlegel H. B., Scuseria G. E., Robb M. A., Cheeseman J. R., Scalmani G., Barone V., Mennucci B., Petersson G. A., Nakatsuji H., Caricato M., Hratchian X., Li H. P., Izmaylov A. F., Bloino J., Zheng G., Sonnenberg J. L., Hada M., Ehara M., Toyota K., Fukuda R., Hasegawa J., Ishida M., Nakajima T., Honda Y., Kitao O., Nakai H., Vreven T., Montgomery J. A. Jr., Peralta J. E., Ogliaro F., Bearpark M., Heyd J. J., Brothers E., Kudin K. N., Staroverov V. N., Keith T., Kobayashi R., Normand J., Raghavachari K., Rendell A., Burant J. C., Iyengar S. S., Tomasi J., Cossi M., Rega N., Millam J. M., Klene M., Knox J. E., Cross J. B., Bakken V., Adamo C., Jaramillo J., Gomperts R., Stratmann R. E., Yazyev O., Austin A. J., Cammi R., Pomelli C., Ochterski J. W., Martin R. L., Morokuma K., Zakrzewski V. G., Voth G. A., Salvador P., Dannenberg J. J., Dapprich S., Daniels A. D., Farkas O., Foresman J. B., Ortiz J. V., Cioslowski J., Fox D. J., Gaussian Inc., Wallingford CT, 2010.

41) Laurie A. T., Jackson R. M., Bioinformatics, 21, 1908-1916 (2005). 